\title{
WAS Gene
}

National Cancer Institute

\section{Source}

National Cancer Institute. WAS Gene. NCI Thesaurus. Code C43236.

This gene is involved in signal transduction and plays a role in cell communication and organization. 